\title{
PENGARUH LINGKUNGAN KERJA DAN GAYA KEPEMIMPINAN \\ TERHADAP KINERJA KARYAWAN PADA PERUSAHAAN CUCI \\ SARANG BURUNG WALET MANGLI JAYA
}

\author{
ALIFIAN NUGRAHA* \\ WINARTI NINGSIH \\ Program Studi Ilmu Administrasi Niaga \\ Sekolah Tinggi Ilmu Administrasi Pembangunan Jember \\ *Email: iandgrahasaputra@gmail.com
}

\begin{abstract}
ABSTRAK
Penelitian ini bertujuan untuk mengetahui pengaruh lingkungan kerja dan gaya kepemimpinan terhadap kinerja karyawan pada perusahaan cuci sarang burung walet Mangli Jaya. Jenis penelitian yang digunakan dalam penelitian ini merupakan penelitian kuantitatif yaitu suatu bentuk pengumpulan data yang bertujuan menggambarkan dan menekankan analisisnya pada data data numerik atau angka guna menguraikan suatu keadaan atau masalah dari objek yang diteliti. Populasi yang digunakan dalam penelitian ini adalah seluruh karyawan Perusahaan Cuci Sarang Burung Walet Mangli Jaya kec. Kaliwates Jember yang berjumlah 31 orang. Mengingat jumlah populasi yang tersedia dalam penelitian ini kecil, maka penelitian ini mengobservasi semua anggota jadi semua populasi dijadikan sampel penelitian. Berdasarkan masalah yang timbul, tujuan penelitian, dan hasil analisis, maka dapat diambil kesimpulan sebagai berikut: Koefisien determinasi dinyatakan nilai Adjusted $R$ Square adalah 0,704 atau 70,4\%.

Regresi berganda dengan persamaan $Y=3,967+0,136 X 1+0,080 \times 2+0,704$ artinya tanpa dipengaruhi apapun maka kinerja karyawan mempunyai nilai konstanta positif sebesar 3,967. Dengan peningkatan satu variabel X1 maka akan meningkatkan kinerja karyawan sebesar 0,136 satuan. Dengan peningkatan satu variabel X2 maka akan meningkatkan kinerja karyawan sebesar 0,080 satuan. Uji secara simultan lingkungan kerja dan gaya kepemimpinan berpengaruh terhadap kinerja karyawan di Perusahaan Cuci Sarang Burung Walet Mangli Jaya kec. Kaliwates Jember. Uji secara parsial hanya satu variabel yang berpengaruh terhadap kinerja karyawan, yaitu variabel gaya kepemimpinan
\end{abstract}

Kata Kunci: Karyawan, Kinerja, Gaya Kepemimpinan 


\section{PENDAHULUAN}

Kinerja karyawan dalam perusahaan memiliki peranan penting dalam mencapai tujuan perusahaan, dengan karyawan yang memiliki kesadaran, kesetiaan, disiplin dan bertanggung jawab atas segala tugas pekerjaan yang diberikan dan dikerjakan sesuai dengan standar maka kinerja perusahaan keseluruhan akan meningkat.

Di dalam perusahaan, sumber daya manusia merupakan salah satu unsur yang terpenting dalam suatu perusahaan. Kemajuan sebuah perusahaan ditentukan oleh kinerja dan keefektifan para karyawan dalam menjalankan tugas pokoknya. Setiap perusahaan mengharapkan karyawan yang bekerja mampu melaksanakan tugas secara efektif dan efisien. Tujuannya agar perusahaan dapat terus meningkatkan daya saing terhadap perusahaan lainnya.

Perusahaan dan karyawan adalah dua pihak yang saling membutuhkan. Menurut Mangkunegara (2010) banyak faktor yang memperngaruhi kinerja, antara lain: motivasi, kepemimpinan, lingkungan kerja, intensif, komunikasi, budaya kerja, kedisiplinan, pendidikan dan pelatihan. Kinerja karyawan dapat diartikan hasil secara kualitas dan kuantitas yang dicapai oleh seorang karyawan dalam melaksanakan tugasnya sesuai dengan tanggung jawab yang diberikan kepadanya.

Setiap pemimpin pada dasarnya memiliki perilaku yang berbeda dalam memimpin para pengikutnya, perilaku para pemimpin itu disebut dengan gaya kepemimpinan.

Tugas pemimpin sebuah perusahaan untuk menciptakan kegiatan yang bertujuan melalui visi, misi, strategi organisasi yang disiapkan sebagai sarana untuk mencapai tujuan organisasi. Pemimpin dalam suatu organisasi dituntut untuk memilih gaya kepemimpinan, seorang pemimpin harus memperhatikan faktor-faktor seperti faktor dari pemimpin itu sendiri, faktor yang ada pada bawahan, dan faktor lingkungan atau situasi dan kondisi yang ada disekitar organisasi.

Berhasil tidaknya perusahaan atau organisasi dalam mencapai 
tujuan selain bergantung pada kepemimpinan dan gaya kepemimpinan juga bergantung pada kualitas sumber daya manusianya, yang ditunjukkan melalui tingkat kedisiplinan kerja.

Kinerja pegawai bukan hanya merupakan hasil kerja yang dicapai seorang dalam melaksanakan tugas yang dibebankan tetapi disiplin kerja pegawai dan perilaku kerja pegawai. Pegawai dapat bekerja dengan baik bila memiliki kinerja yang tinggi sehingga dapat menghasilkan kerja yang baik.

Perusahaan Cuci Sarang Burung Walet Mangli Jaya kec. Kaliwates Jember merupakan perusahaan milik perorangan yang bergerak dibidang jasa perdagangan sarang burung walet dan kondisi nyata melakukan kegiatan aktivitas dibidang ekspor, perusahaan ini kaitannya dengan pemasaran sudah menjangkau ekspor di negara China, namun dalam pengirimannya menggunakan pihak kedua di surabaya. Perusahaan Cuci Sarang Burung Walet Mangli Jaya kec. Kaliwates Jember mempunyai 31 karyawan yang semuanya adalah perempuan sehingga setiap karyawan memiliki keterampilan yang berbeda. Di perusahaan ini karyawan dibagi menjadi 2 bagian yaitu bagian pembersihan berjumlah 25 orang dan bagian cetak 6 orang.

Berdasarkan hasil observasi pada perusahaan Cuci Sarang Burung Walet Mangli Jaya kec. Kaliwates Jember didapatkan beberapa permasalahan yang di hadapi oleh para karyawan, diantaranya pada lingkungan kerja fisik berupa penerangan ditempat kerja, karena diperusahaan ini menggunakan penerangan lampu sehingga ketika listrik padam para karyawan tidak dapat membersihkan sarang burung walet karena kurangnya fasilitas generator yang ada di perusahaan, selain itu sirkulasi udara di perusahaan kurang dikarenakan jendela sedikit dan hanya memiliki 2 kipas angin, hal ini dapat menghambat para karyawan dalam menyelesaikan pekerjaannya ketika cuaca panas karena sirkulasi udara tidak lancar. Untuk lingkungan kerja non fisik berupa hubungan yang harmonis antar karyawan yang masih ada kendala dikarenakan sistem kerja borongan dan perbedaan 
kinerja masing-masing karyawan sehingga terjadi persaingan antara para karyawan, walaupun perusahaan sudah memberi insentif sebagai penunjang semangat kerja karyawan namun tidak semua karyawan mempunyai kesempatan untuk maju dikarenakan setiap karyawan memiliki kreatifitas dan kecekatan dalam bekerja yang berbeda sehingga dapat menentukan pendapatan insentif yang diterima.

\section{TINJAUAN PUSTAKA}

\subsection{Manajemen Sumber Daya} Manusia

Manajemen sumber daya manusia merupakan suatu bidang manajemen yang khusus mempelajari hubungan dan peranan manusia dalam organisasi perusahaan. Beberapa pendapat para ahli tentang definisi manajemen sumber daya manusia, antara lain menurut Hasibuan (2001:10) adalah ilmu dan seni mengatur hubungan dan peranan tenaga kerja agar efektif dan efisien, membantu terwujudnya tujuan perusahaan, karyawan dan masyarakat.
Hal-hal tersebut yang membuat kinerja karyawan menurun.

Berdasarkan latar belakang tersebut maka penulis tertarik untuk melakukan penelitian lebih lanjut dengan mengambil judul "Pengaruh Lingkungan Kerja dan Gaya Kepemimpinan Terhadap Kinerja Karyawan Pada Perusahaan Cuci Sarang Burung Walet Mangli Jaya kec. Kaliwates Jember".

\subsection{Fungsi-Fungsi Pokok Manajemen Sumber Daya Manusia}

Fungsi operasional manajemen sumber daya manusia menurut Jiwanto (1985:11) adalah memperoleh jenis karyawan yang tepat dan jumlah karyawan yang dibutuhkan untuk mencapai tujuan organisasi. Lain halnya, fungsi manajemen sumber daya manusia sama halnya dengan fungsi yang ada dalam manajemen sendiri, seperti apa yang dikemukakan G. Terry dalam bukunya Principle of Management yang menyatakan bahwa, fungsi manajemen meliputi 
Planning, Organizing, Actuating dan Controlling (POAC).

\subsection{Kepemimpinan}

Kepemimpinan

berarti

kemampuan dan kesiapan yang dimiliki oleh seseorang untuk dapat mempengaruhi, mendorong, mengajak, menuntun, menggerakan, dan mengarahkan orang atau kelompok agar menerima pengaruh tersebut dan selanjutnya berbuat sesuatu yang dapat membantu tercapainya suatu tujuan tertentu yang telah ditetapkan.

Pada dasarnya kepemimpinan meliputi proses mempengaruhi dalam menentukan tujuan organisasi atau instansi, memotivasi perilaku bawahan untuk mencapai tujuan, mempengaruhi untuk perbaikan kelompok. Hal tersebut dapat dilihat dari keberhasilan seorang pemimpin dalam menggerakan orang lain dalam mencapai tujuan.

\subsection{Teori Kepemimpinan}

Teori kepemimpinan yang dikemukakan oleh Veitzhal Rivai, Deddy Mulyadi (2012:7) mengemukakan bahwa teori yang berusaha untuk mengidentifikasikan karekteristik khas (fisik, mental, kepribadian) yang dikaitkan dengan keberhasilan kepemimpinan. Teori mengenai kepemimpinan dapat digolongkan kedalam dua pendekatan utama, yaitu:

1. Pendekatan Sifat

2. Pendekatan Kepribadian Perilaku

\subsection{Tipe Kepemimpinan}

Kepimpinan di dalam melaksanakan fungsi-fungsinya, maka akan berlangsung aktivitas kepimpinan. Apabila aktivitas dapat dicapai dan sesuai dengan rencana maka akan terlihat gaya kepimpinan dengan polanya masing- masing. Veitzhal Rivai (2012:42) mengemukakan gaya kepemimpinan memiliki tiga pola dasar, yaitu:

1. Gaya kepimpinan yang berpola pada kepentingan pelaksanaan tugas

2. Gaya kepimpinan yang berpola pada pelaksanaan hubungan kerja sama.

3. Gaya kepemimpinan yang berpola pada kepentingan hasil yang dicapai. 


\subsection{Lingkungan Kerja} lingkungan yang berada disekitar pegawai karena mereka bekerja sama untuk mencapai tujuan bersama. Masalah lingkungan kerja perlu diperhatikan karena akan berdampak, dalam proses produktivitas.

Lingkungan kerja adalah tempat dimana pegawai melakukan aktivitas setiap harinya. Lingkungan kerja yang kondusif memberikan rasa aman dan memungkinkan pegawai bekerja dengan optimal. Jika pegawai menyenangi lingkungan kerja dimana dia bekerja, maka pegawai tersebut merasa nyaman di tempat kerjanya dan melakukan aktivitas sehingga waktu kerja dipergunakan secara efektif.
Lingkungan kerja adalah

\subsection{Kinerja Pegawai}

Kinerja pegawai memiliki peran yang sangat penting dalam melaksanakan setiap pekerjaan dengan harapan tercapainya tujuan perusahaan. Tujuan perusahaan akan sulit untuk dicapai apabila banyak pegawai yang tidak menyelesaikan pekerjaan dengan baik dan tidak tepat waktu hal ini akan merugikan perusahaan.

Tujuan evaluasi kinerja adalah untuk memperbaiki dan meningkatkan kinerja organisasi melalui peningkatan kinerja Sumber Daya Manusia (SDM) organisasi, dalam penilaian kinerja tidak hanya semata-mata menilai hasil fisik tetapi pelaksanaan pekerjaan secara keseluruhan yang menyangkut berbagai bidang seperti kemampuan, kerajinan, disiplin, hubungan kerja, atau hal-hal khusus sesuai dengan bidang dan tugasnya semua layak untuk dinilai.

\section{METODE PENELITIAN}

\subsection{Jenis Penelitian}

Jenis penelitian yang digunakan dalam penelitian ini merupakan penelitian kuantitatif yaitu suatu bentuk pengumpulan data yang bertujuan menggambarkan dan menekankan analisisnya pada data data numerik atau angka guna 
menguraikan suatu keadaan atau masalah dari objek yang diteliti. Unit analisis dalam penelitian ini adalah seluruh karyawan di Perusahaan Cuci Sarang Burung Walet Mangli Jaya kec. Kaliwates Jember.

\subsection{Tempat dan Waktu Penelitian}

Dalam penelitian ini lokasi yang dipilih menjadi objek penelitian adalah Perusahaan Cuci Sarang Burung Walet Mangli Jaya yang beralamat di Jl. Otto Iskandar Dinata No. 22-23 Mangli kec. Kaliwates Jember. Operasional penelitian dilakukan selama 3 bulan pada bulan Agustus - Desember 2018.

\subsection{Populasi dan Sampel}

Populasi yang digunakan dalam penelitian ini adalah seluruh karyawan Perusahaan Cuci Sarang Burung Walet Mangli Jaya kec. Kaliwates Jember yang berjumlah 31 orang. Mengingat jumlah populasi yang tersedia dalam penelitian ini kecil, maka penelitian ini mengobservasi semua anggota jadi semua populasi dijadikan sampel penelitian. Teknik pengambilan sampel dengan menggunakan metode sampel jenuh.

\subsection{Definisi Operasional}

Variabel-variabel yang digunakan dalam penelitian ini perlu diidentifikasi terlebih dahulu agar tidak terdapat perbedaan cara pandang terhadap variabel penelitian. Variabel yang diidentifikasi sebagai variabel bebas adalah Lingkungan Kerja $\left(\mathrm{X}_{1}\right)$ dan Gaya Kepemimpinan $\left(\mathrm{X}_{2}\right)$. Sedangkan variabel terikat adalah Kinerja Karyawan (Y).

1. Variabel Bebas/Independent

\section{Variable (X)}

Variabel bebas adalah variabel yang mempengaruhi atau yang menjadi sebab perubahan atau timbulnya variabel terikat (Sugiyono, 2013:43).

a. Lingkungan Kerja (X1)

Lingkungan kerja adalah keseluruhan alat perkakas dan bahan yang dihadapi, lingkungan sekitarnya dimana seseorang bekerja, metode kerjanya, serta pengaturan kerjanya baik sebagai perseorangan maupun sebagai kelompok, dapat ditarik 
kesimpulannya bahwa kondisi

lingkungan kerja yang baik akan menunjang produktivitas karyawan yang pada akhirnya berdampak pada kenaikan tingkat kinerja karyawan.

b. Gaya Kepemipinan

Teori kepemimpinan yang dikemukakan oleh Veitzhal Rivai, Deddy Mulyadi (2012:7) mengemukakan bahwa teori yang berusaha untuk mengidentifikasikan karekteristik khas (fisik, mental, kepribadian) yang dikaitkan dengan keberhasilan kepemimpinan. Teori

2. Variabel Terikat/Dependent Variable (Y)

Variabel terikat merupakan variabel yang dipengaruhi atau yang terjadi akibat karena adanya variabel bebas (Sugiyono, 2013:43). Variabel terikat dalam penelitian ini adalah Kinerja karyawan (Y).

Kinerja adalah hasil kerja (output) baik kualitas maupun kuantitas yang dicapai karyawan dalam melaksanakan pekerjaan sesuai dengan tanggung jawab yang diberikan kepadanya.

\subsection{Jenis dan Sumber Data}

1. Jenis Data

Data dalam penelitian ini menggunakan data interval, dikarenakan menggunakan skala likert.

2. Sumber Data

Ada dua jenis data, yaitu data primer dan data sekunder.

a. Data Primer

Data primer pada penelitian ini adalah hasil kuisioner yang langsung dibagikan dan di isi oleh selutuh karyawan di Perusahaan Cuci Sarang Burung Walet Mangli Jaya Kec. Kaliwates Jember.

b. Data Sekunder

Data sekunder adalah sumber data yang tidak langsung memberikan data kepada pengumpul data (Sugiyono, 2013). . 


\section{HASIL PENELITIAN DAN PEMBAHASAN}

\subsection{Uji Validitas}

Uji signifikansi dilakukan dengan membandingkan nilai $r_{h i t u n g}$ dengan $\mathrm{r}_{\text {tabel }}$ untuk degree of freedom $(\mathrm{df})=\mathrm{n}-2, \quad \mathrm{n} \quad$ dalam penelitian ini adalah jumlah sampel. Jumlah sampel dalam penelitian ini adalah 31 dan besarnya df dapat dihitung 31-2=29. Dengan $\mathrm{df}=29$ dan pada taraf signifikan $95 \%$ atau alpha (a) $5 \%$ diperoleh $r_{\text {tabel }}=0,3550$. Jika $r_{\text {hitung }}>r_{\text {tabel }}$ dan nilai positif maka item pertanyaan atau indikator dinyatakan valid (Ghozali, 2013:45).

Tabel 1. Uji Validitas

\begin{tabular}{|c|c|c|c|c|}
\hline Varinbed & fiem & f Mitang & r rabed & Ket. \\
\hline \multirow[t]{3}{*}{ 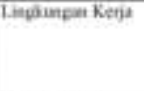 } & Qi & Q.K24 & 0.3559 & Valid \\
\hline & 02 & करक & 0.3590 & valial \\
\hline & Q) & Q.:514 & करज्ञा & Vastia \\
\hline \multirow[t]{3}{*}{ Kepeminpuas } & o1 & (6) & 05901 & valia \\
\hline & का & Q., 87 & Q5951 & velia \\
\hline & (3) & 0,914 & 0.3590 & Valia \\
\hline \multirow[t]{3}{*}{ Kinerio Karyamin } & Q1 & 0.967 & 0.3550 & Volial \\
\hline & $\omega_{2}$ & 0,255 & 0.3550 & Valia \\
\hline & 93 & 0.959 & 0.3590 & Velia \\
\hline
\end{tabular}

Sumber : Data diolah (2018)

Berdasarkan Tabel diatas dapat diketahui bahwa nilai dari $r_{\text {hitung }}$ keseluruhan item yang diuji bernilai positif dan lebih besar daripada nilai $r_{\text {tabel }}$. Maka dapat disimpulkan bahwa seluruh item pernyataan yang digunakan dalam penelitian ini lolos dalam uji validitas dan dinyatakan valid.

\subsection{Uji Realibilitas}

Reliabilitas melalui perhitungan SPSS diukur dengan uji statistik Cronbach Alpha, variabel dikatakan reliabel jika memberikan nilai Cronbach Alpha > 0,6.

Tabel 2. Uji Reabilitas

\begin{tabular}{|c|c|c|}
\hline Variabel & Cnutbuch's Alphe & Ketteranges \\
\hline Lingkingan Kerji & 0,749 & Relinbel \\
\hline Kepeminpinan & 0.885 & Reliabl| \\
\hline Kineria Lisaha & 0,777 & Reliabel \\
\hline
\end{tabular}

Sumber: Data diolah (2018)

Berdasarkan tabel diatas dapat diketahui nilai Cronbach Alpha seluruh Item variabel >0,6. Maka dapat dapat disimpulkan bahwa seluruh item pernyataan yang digunakan dalam penelitian ini dinyatakan reliabel.

\subsection{Uji Asumsi Klasik}

Analisis yang dilakukan untuk menilai apakah di dalam sebuah model regresi linear Ordinary Least Square (OLS) terdapat masalahmasalah asumsi klasik.

\section{Uji Normalitas}

Tabel 3. Uji Normalitas

\begin{tabular}{|l|r|}
\hline \multicolumn{2}{|c|}{ Lnstandordized Rosidual } \\
\hline Kolwogerow-Smirnoy Z & 0,149 \\
\hline Aymp. Sig. (2-fwiled) & 0,079 \\
\hline
\end{tabular}

Sumber : Data diolah (2018) 
Dapat diketahui nilai Kolmogorov-Smirnov $Z$ adalah 0,149 dan nilai Asymp. Sig. $=0,079$ lebih besar dari 0,05. Dapat disimpulkan bahwa data yang telah diolah memiliki nilai residual normal.

\section{Uji Heteroskedastisitas}

Salah satu cara untuk mendeteksi adalah dengan uji glejser, dengan kriteria pengujian jika semua variabel bernilai $\mathrm{t}$ hitung $<\mathrm{t}$ tabel dan nilai sig. > 0,05 maka tidak terjadi heteroskedaktisitas, namun jika $\mathrm{t}$ hitung $>\mathrm{t}$ tabel dan nilai sig. $<0,05$ maka terjadi heteroskedaktisitas. Dan $\mathrm{t}$ tabel diperoleh dari $\mathrm{df}=\mathrm{n}-\mathrm{k}$ atau 313=28 maka diperoleh $t_{\text {tabel }}$ sebesar 1,701 .

Tabel 4. Uji Heteroskedastisitas

\begin{tabular}{|c|c|c|c|}
\hline Variabed & tmens & sig. & Keteraugan \\
\hline Lingkungan Kaje & 1.450 & 0.156 & Betas Heternekedustisitas \\
\hline Kepsmimpinan & 1.143 & 0263 & 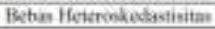 \\
\hline
\end{tabular}

Sumber : Data diolah (2018)

\section{Uji Multikolinearitas}

Apabila nilai Tolerance $<0,10$ dan nilai $V I F>10$, maka terjadi multikolinearitas. Tetapi apabila nilai Tolerance $>0,10$ dan nilai $V I F<10$, maka tidak terjadi multikolinearitas.

Tabel 5. Uji Uji Multikolinearitas

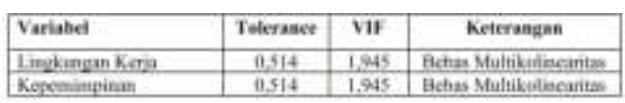

Sumber : Data diolah (2018)

\subsection{Analisis Koefisien Determinasi $\left(\mathbf{R}^{2}\right)$ \\ Koefisien determinasi digunakan} untuk mengetahui seberapa besar pengaruh variabel bebas terhadap variabel terikatnya. Nilai koefisien determinasi ditentukan dengan nilai Adjusted $R$ Square sebagaimana dapat dilihat pada tabel berikut :

Tabel 6. Analisis Koefisien Determinasi (R2)

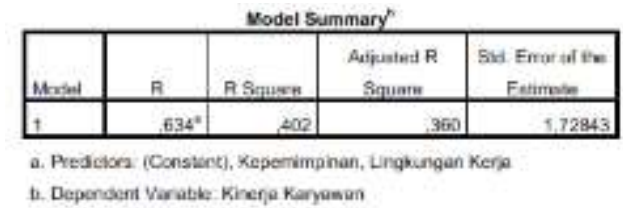

Sumber : Data diolah (2018)

Diketahui nilai Adjusted $R$ Square sebesar 0,402atau 40,2\% yang berarti bahwa sumbangan atau kontribusi dari variabel Lingkungan Kerja $\left(\mathrm{X}_{1}\right)$ dan Kepemimpinan $\left(\mathrm{X}_{2}\right)$ terhadap Kinerja Karyawan (Y) sebesar 0,402. Sedangkan sisanya dapat dihitung dengan rumus sebagai berikut:

$$
\begin{aligned}
& e=1-R^{2} \\
& e=1-0,402 \\
& e=0,598 \text { atau } 59,8 \%\left(\text { nilai } e_{1}\right) \\
& \text { Angka } 59,8 \% \quad \text { mempunyai }
\end{aligned}
$$
makna besarnya faktor lainnya yang tidak diterangkan pada penelitian ini. 
4.5 Analisis Regresi Linier

\section{Berganda}

Analisis ini untuk mengetahui arah hubungan antara variabel independen dengan variabel dependen apakah masing-masing variabel independen berhubungan positif atau negatif dan untuk memprediksi nilai dari variabel dependen apabila nilai variabel independen mengalami kenaikan atau penurunan.

Tabel 7. Analisis Regresi Linier Berganda

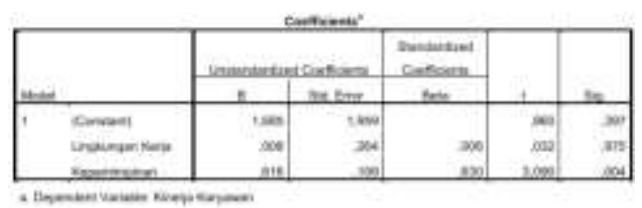

Sumber : Data diolah (2018)

Dari Tabel diatas dapat diperoleh persamaan regresi $\mathbf{Y}=$ $1,685+0,008 X 1+0,616 \times 2$, dari persamaan tersebut dapat diinterpretasikan sebagai berikut:

1. Konstanta $(\mathrm{a})=1,685$

Nilai konstanta positif sebesar 1,820, tanda positif menunjukkan hubungan yang searah. Artinya jika lingkungan $\operatorname{kerja}\left(\mathrm{X}_{1}\right) \quad$ dan kepemimpinan $\left(\mathrm{X}_{2}\right)$ dikontrol (dianggap konstan), maka variabel kinerja Karyawan (Y) akan naik.
2. Koefisien Lingkungan kerja $\left(X_{1}\right)$ $=0,008$

Variabel lingkungan kerja $\left(\mathrm{X}_{1}\right)$ memiliki pengaruh positif terhadap kinerja karyawan (Y) yaitu sebesar 0,008 . Tanda positif menunjukkan hubungan yang searah. Artinya, jika lingkungan $\operatorname{kerja}\left(\mathrm{X}_{1}\right)$ naik dan kepemimpinan $\left(\mathrm{X}_{2}\right)$ dikontrol (dianggap konstan), maka kinerjakaryawan (Y) akan naik.

3. Koefisien Kepemimpinan $\left(\mathrm{X}_{2}\right)=$ 0,616

Variabel kepemimpinan $\left(\mathrm{X}_{2}\right)$ memiliki pengaruh positif terhadap kinerja karyawan (Y) yaitu sebesar 0,616 . Tanda positif menunjukkan hubungan yang searah. Artinya, jika kepemimpinan $\left(\mathrm{X}_{2}\right)$ dan lingkungan kerja $\left(\mathrm{X}_{1}\right)$ dikontrol (dianggap konstan), maka kinerja karyawan akan naik.

\subsection{Uji F (Simultan)}

Uji F dilakukan dengan membandingkan nilai $\mathrm{F}_{\text {hitung }}$ dengan $\mathrm{F}$ Tabel . Untuk degree of freedom $(\mathrm{df} 1)=\mathrm{k}-1, \mathrm{df} 2=\mathrm{n}-\mathrm{k}$. besarnya $\mathrm{df}$ adalah df $1=3-1=2, \mathrm{df}=31-3=28$, pada taraf signifikan $95 \%$ atau alpha 


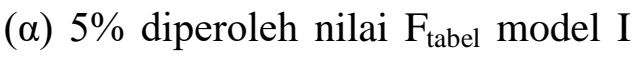
$=3,32$.

Tabel 8. Uji F (Simultan)

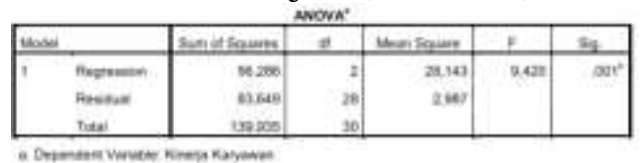

Sumber : Data diolah (2018)

Dapat dilihat bahwa nilai $F_{\text {hitung }}$ $>\mathrm{F}_{\text {tabel }}$, yaitu 9,420 > 3,32 dengan nilai signifikansi 0,01 . Dengan nilai $\mathrm{F}_{\text {hitung }}>\mathrm{F}_{\text {tabel }}$ dan nilai signifikannya $<0,05$, hal ini berarti Ha diterima. Artinya variabel lingkungan kerja dan kepemimpinan secara bersamasama berpengaruh terhadap kinerja karyawan

\subsection{Uji t (Parsial)}

Kriteria pengujian dengan tingkat signifikasi $(\alpha)=0,05$ ditentukan sebagai berikut:

Tabel 9. Uji t

\begin{tabular}{|c|c|c|c|c|}
\hline Variabel & tistat & $t_{\text {thase }}$ & Sig & Keteruagan \\
\hline Lingkungin Kerpa & 1.701 & 0.032 & 0,975 & Ditolak \\
\hline Kepemimpinan & 1,701 & 3,040 & 0,004 & Ditenima \\
\hline
\end{tabular}

a) Apabila $\mathrm{t}_{\text {hitung }}>\mathrm{t}$ tabel, maka $\mathrm{H}_{0}$ ditolak dan Ha diterima

b) Apabila $\mathrm{t}_{\text {hitung }}<\mathrm{t}$ tabel, maka $\mathrm{Ha}$ diterima dan $\mathrm{H}_{0}$ ditolak

c) t tabel diperoleh dengan derajat bebas $(\mathrm{df}): \mathrm{df}=\mathrm{n}-\mathrm{k}$ d) $t$ tabel model I : $31-3=28$ maka diperoleh nilai $\mathrm{t}$ tabel $=$ 1,701 .

\subsection{Pembahasan Hasil Penelitian}

Berdasarkan hasil penelitian yang telah dilakukan yaitu pengaruh lingkungan kerja dan gaya kepemimpinan terhadap kinerja karyawan di perusahaan cuci sarang burung walet mangli jaya kec. Kaliwates Jember, kabupaten Jember, dapat diketahui bahwa hipotesis 1 diterima, artinya lingkungan kerja dan gaya kepemimpinan secara simultan berpengaruh terhadap kinerja karyawan. Hal ini terjadi karena karyawan terlibat secara langsung dalam suasana lingkungan kerja yang ada di perusahaan dan pemberian insentif yang diterima oleh karyawan. Hasil penelitian ini mendukung teori dari Sedarmayanti (2001) yang menyatakan bahawa lingkungan kerja adalah keseluruhan alat perkakas dan bahan yang dihadapi, lingkungan sekitarnya dimana seseorang bekerja, metode kerjanya, serta pengaturan kerjanya baik sebagai perseorangan maupun 
sebagai kelompok, dapat ditarik kesimpulannya bahwa kondisi lingkungan kerja yang baik akan menunjang produktivitas karyawan yang pada akhirnya berdampak pada kenaikan tingkat kinerja karyawan, serta menurut Sarwoto (2010), gaya kepemimpinan merupakan perangsang ataupun pendorong yang diberikan dengan sengaja kepada para pekerja agar dalam diri mereka timbul semangat yang lebih besar untuk berprestasi bagi organisasi.

Hasil pengujian hipotesis secara parsial menunjukkan bahwa hipotesis 1 ditolak, artinya variabel lingkungan kerja tidak berpengaruh secara signifikan terhadap kinerja karyawan di perusahaan cuci sarang burung walet mangli jaya kec. Kaliwates Jember. Hal ini bertentangan dengan teori Mangkunegara (2004) yang menyatakan lingkungan kerja mempunyai hubungan yang sangat erat terhadap kinerja karyawan, motif berprestasi yang perlu dimiliki oleh karyawan harus di tumbuhkan dari dalam diri sendiri dan dari lingkungan kerja, karena motif berprestasi yang ditumbuhkan dari dalam diri sendiri akan membentuk suatu kekuatan diri dan jika situasi lingkungan kerja turut menunjang maka pencapaian kinerja akan lebih mudah. Berdasarkan penjelasan dan hasil yang didapat dapat ditarik kesimpulan bahwa dalam penelitian ini responden atau karyawan di perusahaan cuci sarang burung walet mangli jaya tidak memperhatikan variabel lingkungan kerja dalam menjalankan pekerjaan dikarenakan lingkungan kerja itu sendiri sudah terlalu melekat pada karyawan sehingga tidak disadari, Penelitian ini tidak mendukung penelitian yang telah dilakukan Dori Mittra Candana (2018), Lia Cahya Ningtyas N, dkk, (2013) dan Siti Lilatul Iklima (2017). yang menyatakan bahwa secara parsial faktor lingkungan kerja berpengaruh signifikan terhadap kinerja karyawan.

Hasil pengujian hipotesis secara parsial menunjukkan bahwa hipotesis 1 diterima, artinya variabel gaya kepemimpinan berpengaruh secara signifikan terhadap kinerja karyawan di perusahaan cuci sarang burung walet mangli jaya kec. Kaliwates Jember. 


\section{KESIMPULAN DAN SARAN}

\subsection{Kesimpulan}

Berdasarkan masalah yang timbul, tujuan penelitian, dan hasil analisis, maka dapat diambil kesimpulan sebagai berikut:

Koefisien determinasi $\left(\mathrm{R}^{2}\right)$ dinyatakan nilai Adjusted $R$ Square adalah 0,704 atau $70,4 \%$. Hal ini menunjukkan bahwa kinerja karyawan dipengaruhi oleh semua faktor lingkungan kerja dan gaya kepemimpinan sebesar 0,704 atau $70,4 \%$, sementara faktor yang tidak masuk dalam penelitian sebesar $29,6 \%$.

Regresi berganda dengan persamaan

$Y=3,967+0,136 X_{1}+0,080 X_{2}+0,704$

artinya tanpa dipengaruhi apapun maka kinerja karyawan mempunyai nilai konstanta positif sebesar 3,967. Dengan peningkatan satu variabel $X_{1}$ maka akan meningkatkan kinerja karyawan sebesar 0,136 satuan. Dengan peningkatan satu variabel $\mathrm{X}_{2}$ maka akan meningkatkan kinerja karyawan sebesar 0,080 satuan.

Uji secara simultan mempunyai $F_{\text {hitung }}(7,322)>F_{\text {tabel }}(3,39)$ dan nilai signifikansi sebesar 0,003 lebih kecil dari 0,05, artinya secara simultan lingkungan kerja dan gaya kepemimpinan berpengaruh terhadap kinerja karyawan di Perusahaan Cuci Sarang Burung Walet Mangli Jaya kec. Kaliwates Jember.

Uji secara parsial hanya satu variabel yang berpengaruh terhadap kinerja karyawan, yaitu variabel insentif yang mempunyai nilai $\mathrm{t}$ hitung $(3,665)>$ ttabel $(1,701)$ dan nilai signifikansi sebesar $0,001<0,05$, hal ini menunjukkan bahwa faktor gaya kepemimpinan berpengaruh secara parsial terhadap kinerja karyawan di Perusahaan Cuci Sarang Burung Walet Mangli Jaya kec. Kaliwates Jember.

\subsection{Saran}

Berdasarkan keterbatasan penelitian, maka saran yang diajukan dalam penelitian ini yaitu:

1. Diharapkan pihak perusahaan dapat meningkatkan pelayanan terhadap lingkungan kerja fisik, karena variabel lingkungan kerja mempengaruhi kinerja karyawan, diantaranya yaitu dengan sirkulasi udara dan 
penerangan yang memadai.

2. Untuk seluruh karyawan hendaknya memperbaiki hubungan yang belum harmonis agar hubungan yang ada dalam perusahaan selalu harmonis.

3. Mengingat variabel bebas dalam penelitian ini merupakan hal yang sangat penting dalam mempengaruhi kinerja karyawan diharapkan hasil penelitian ini

\section{DAFTAR PUSTAKA}

A.A. Anwar Prabu Mangkunegara, (2002), Manajemen Sumber Daya Manusia,

PT. Remaja Rosda Karya. Bandung. , 2004, Manajemen Sumber

Daya Manusia Perusahaan, Bandung. PT.Remaja Rosdakarya. 2005. Manajemen Sumber daya Manusia Perusahaan. Bandung : PT

Remaja Rosdakarya.

Agus Dharma. 2001. Manajemen Supervisi. Raja Grafindo Persada. Jakarta.

Arikunto, S. 2002. Metodologi Penelitian Suatu Pendekatan Proposal. Jakarta: PT. Rineka Cipta. . 2006. Metode Penelitian Kualitatif. Jakarta: Bumi Aksara.

Gomes, Faustino Cardoso. 2003. Manajemen Sumber Daya Manusia. Jakarta: Andi Offset. dapat dipakai sebagai acuan bagi peneliti selanjutnya untuk mengembangkan penelitian ini dengan mempertimbangkan variabel-variabel lain yang merupakan variabel lain diluar variabel yang sudah masuk dalam penelitian ini seperti motivasi karyawan, dukungan atasan terhadap bawahan dan keberadaan pekerjaan.
. 2010. Manajemen Sumber
Daya
Yogyakarta.
Ghozali, Imam. 2001. Aplikasi Ghozali, Imam. 2001. Aplikasi
Analisis Multivariate Dengan Program SPSS.

Semarang: Badan Penerbit Universitas Diponegoro. . 2013. Aplikasi Analisis Multivariate dengan Program SPSS.

Edisi Ketujuh. Semarang : Badan Penerbit Universitas Diponegoro.

Herman, Sofyandi. 2008. Manajemen Sumber Daya Manusia. Yogyakarta : Graha Ilmu.

Hasibuan, Malayu. 2001. Manajemen Sumber Daya Manusia:Pengertian

Dasar, Pengertian, dan Masalah. Jakarta: PT. Toko Gunung Agung. 
. 2012. "Manajemen Sumber

Daya manusia". Jakarta: PT Bumi Aksara.

Isyandi, B, 2004. Manajemen Sumber Daya Manusia Dalam Perspektif Global.Pekanbaru. Unri Press.

Ir. M. Iqbal Hasan, M.M., 2005,"Pokok - Pokok Materi Statistik 2 “, PT Bumi

Aksara, Jakarta, Cetakan ketiga.

Justin.T.Sirait, 2006. Memahami Aspek-aspek Pengelolaan Sumber Daya

Manusia dalam. Organisasi. Gramedia Widiasarana Indonesia. Jakarta.

Mayangsari, Lia. 2013. Pengaruh Pemberian Insentif Terhadap Kinerja

Karyawan Di Departemen Penjualan Pt. Pusri. Skripsi Kementerian Pendidikan Dan Kebudayaan Universitas Sriwijaya Fakultas Ekonomi.

Nuraini, T. 2013. Manajemen Sumber Daya Manusia.Pekanbaru:

YayasanAini Syam.

Panggabean, Mutiara S, (2002). Manajemen Sumber Daya Manusia. Jakarta

:GhaliaIndonesia.

Rivai, Veithzal. 2004, "Manajemen Sumber Daya Manusia Untuk Perusahaan,Cetakan

Pertama,Jakarta. PT. Raja Grafindo Persada. . 2009. Manajemen Sumber Daya Manusia Untuk Perusahaan Dari Teori ke Praktik. Jakarta: Raja Grafindo Persada.
Sarwoto. (2010). Dasar-Dasar Organisasi Dan Manajemen. Cetakan

Keenambelas. Jakarta: Ghalia Indonesia

Sedarmayanti. 2001. Sumber Daya Manusia dan Produktivitas Kerja. Bandung: Mandar Maju. (2004).Sumber Daya Manusia dan Produktivitas Kerja. Bandung: Mandar Maju.

(2013). Manajemen Sumber Daya Manusia. Bandung: RefikaAditama.

Setiyawan, Budi dan Waridin. 2006. Pengaruh Disiplin Kerja Karyawan Dan

Soetjipto, Budi W, Paradigma Baru Manajemen Sumber Daya Manusia.Yogyakarta: Amara Book. 2008.

Sutrisno, Edy. 2015. Manajemen Sumber Daya Manusia(Cetakan ke tujuh).

Jakarta: Kencana Prenada Media Group.

Sugiyono.2006.Metode Penelitian Kuantitatif, Kualitatif dan R $\& D$. Bandung:Alfabeta. . 2009, Metode Penelitian Kuantitatif, Kualitatif dan R\&D, Bandung : Alfabeta. 2012.Metode Penelitian Bisnis. Bandung : Alfabeta. . 2013. Metode Penelitian Pendidikan Pendekatan Kuantitatif,

Kualitatif, dan R\&D. Bandung: Alfabeta.

Usman, Husaini. 2003. Metodologi Penelitian Sosial. Jakarta: Bumi Aksara. 